International Water Resources Association

Water International, Volume 28, Number 2, Pages 154-161, June 2003

\title{
Groundwater Resources and International Law in the Middle East Peace Process
}

\author{
Yoram Eckstein, Kent State University, Kent, Ohio, USA and Gabriel E. Eckstein, \\ Attorney at Law, Washington, D.C., USA
}

\begin{abstract}
Next to issues of land, water resources are the major bone of contention in the peace negotiations between Israel and the Palestinian Arabs. The objective of negotiations is de facto setting the clock back to the eve of the Israel War of Independence, when the Jews accepted the 1947 UN resolution of partition, while the Arabs rejected it. The Arabs now accept the principle of territorial partition, but at the same time, they demand re-apportioning of resources, mainly of water. The Palestinians contend that the facts created on the ground unilaterally by Israel during the last 50 years, namely the agricultural development and the high water consumption by the Israeli urban sector, leave them without resources necessary for their development as a modern society. Per capita annual renewable freshwater resources in the region is among the lowest in the world. Approximately 600 million $\mathrm{m}^{3}$, or about one-third of the regional fresh groundwater consumption, is annually abstracted from aquifer systems recharged at the uplands of the Upper Cretaceous partly karstified carbonate formations of Judea and Samaria, terrenes often referred to as the West Bank. Israel and the Israeli agricultural settlements established within Judea and Samaria use 495 million $\mathrm{m}^{3} /$ year (or 82.5 percent) of the abstracted water, leaving to the Palestinians the remaining 105 million $\mathrm{m}^{3} / y e a r$. Thus, while the recharge zone to the Judean and Samarian aquifer systems are within the territories with an overwhelmingly Palestinian majority, most of the discharge occurs through water wells within the Israeli administration. The situation is reversed in the Gaza Strip, where Israel allows underflow of only 7 million $\mathrm{m}^{3 /}$ year of groundwater across the border, a less than 10 percent contribution to the nearly 80 million $\mathrm{m}^{3}$ year overdrawn water budget of the area. The issue of water is complicated by glaringly wide disparity in per capita water consumption between the two nations. While lines on the ground may separate two nations with conflicting territorial ambitions, apportioning of groundwater between Israel and the future Palestinian State proves to be one of the most intractable issues in the Middle East Peace Process. Moreover, neither international nor domestic law provides an adequate answer to questions of ownership or rights.
\end{abstract}

\section{Introduction}

Shortage of water is among the most serious problems facing the Israel-Palestinian region. It is possibly one of the most intractable issues of the multidimensional dispute between Israel and the current precursors of the Palestinian State. The region has one of the smallest annual per capita renewable water resources in the world (Table 1).

Water scarcity has always been the dominant factor in populations of the Middle East. Throughout the entire area, from Egypt to the fertile valleys of Iraq, man has had to depend on scanty and erratic seasonal rains or on rivers for water. The climate of the Israeli-Palestinian area west of the Jordan-Dead Sea trough is strongly affected by the desert regions to the south and east. Approximately 60 percent of that area is categorized as arid or semi-arid. Average annual rainfall ranging from 400 to $800 \mathrm{~mm}$ in the northern and western part of the country, and sharply declining to the south and east, occurs mainly between November and March. The remainder of the year endures a hot dry season with practically no significant rainfall.

Under such circumstances, conflict about the division of the scant water resources of the region is second or equal to the territorial dispute between Israel and the emerging Palestinian State. This is particularly true considering the glaring differences between the annual per capita water consumption in the Israeli and the Palestinian sectors (Table 2).

\section{Hydrogeology}

About one-third of the State of Israel's national water consumption, some 600 million $\mathrm{m}^{3} /$ year, of water is produced from the Upper Cretaceous aquifers (often referred 
Table 1. Approximate Annual Per Capita Renewable Water Resources in the Middle East

\begin{tabular}{|c|c|c|c|c|c|c|}
\hline \multirow[t]{2}{*}{ Country } & \multicolumn{3}{|c|}{ Renewable Resources Per Capita( $\mathrm{m}^{3} /$ year $)$} & \multicolumn{3}{|c|}{ Share of Withdrawals (\%) } \\
\hline & 1960 & 1990 & 2025 & Residential & Industry & Agriculture \\
\hline Israel & 1,025 & 467 & 311 & 16 & 5 & 79 \\
\hline Jordan & 529 & 224 & 91 & 29 & 6 & 65 \\
\hline Lebanon & 2,000 & 1,407 & 809 & 11 & 4 & 85 \\
\hline Iraq & 14,706 & 5,285 & 2,000 & 3 & 5 & 92 \\
\hline Oman & 4,000 & 1,333 & 421 & 3 & 3 & 94 \\
\hline Saudi Arabia & 537 & 156 & 49 & 6 & 2 & 91 \\
\hline UAE & 3,000 & 189 & 113 & 11 & 9 & 80 \\
\hline Yemen & 481 & 214 & 72 & 5 & 2 & 93 \\
\hline
\end{tabular}

(adapted from Gleick, 1993)

Table 2. Annual Water Consumption

\begin{tabular}{|c|c|c|c|c|c|}
\hline \multirow[t]{2}{*}{$\begin{array}{l}\text { Annual Water } \\
\text { Consumption } \\
\text { in Various } \\
\text { Sectors }\end{array}$} & \multicolumn{2}{|c|}{$\begin{array}{l}\text { Judea and Samaria } \\
\text { (West Bank) }\end{array}$} & \multicolumn{2}{|c|}{ Gaza Strip } & \multirow[t]{2}{*}{ Israel } \\
\hline & Palestians & Settlers & Palestinians & Settlers & \\
\hline $\begin{array}{l}\text { Total (million } \\
\mathbf{m}^{3} / \text { year) }\end{array}$ & 125 & 45 & 103 & 6 & 1,770 \\
\hline Agriculture & 95 & n.a. & 80 & n.a. & 1,320 \\
\hline Residential & 27 & n.a. & 20 & n.a. & 325 \\
\hline Industrial & 3 & n.a. & 2 & n.a. & 125 \\
\hline $\begin{array}{l}\text { Per capita } \\
\left(\mathrm{m}^{3} / \text { year }\right)\end{array}$ & 139 & 1,143 & 172 & 2,326 & 411 \\
\hline Agriculture & 106 & n.a. & 133 & n.a. & 307 \\
\hline Residential & 30 & 85 & 35 & 85 & 75 \\
\hline Industrial & 3 & 3 & 29 & n.a. & n.a. \\
\hline
\end{tabular}

(Adapted from United Nations, 1991).

n.a. $=$ not available

to as the Mountain Aquifer) that are recharged along the axial part of the Samarian-Judean Anticlinorium running along the north-south direction through most of the West Bank territory. Groundwater recharged along the high ridges of the anticlinorial axis diverge into three directions along the structural slopes: to the west (so called Western Basin or Yarqon-Tanninim Aquifer) towards the Coastal Plain, to the east (so called Eastern Basin) towards the Jordan-Dead Sea trough, and to the north (so called Northeastern Basin) draining towards Valley of Jezreel (Esdraelon) and Beit Shean Valley (Figure 1). Thus, hydrogeologically, the pre-1967 Israeli territories are downstream of the Western and the Northern Aquifers. In essence, groundwater flows (albeit at an extremely slow rate) from the recharge areas along the high ridges populated by the Palestinians across the 1967 "green line" boundaries into Israel. Groundwater in the three basins will be considered a transboundary water resource between Israel and the future Palestinian State, and in the light of

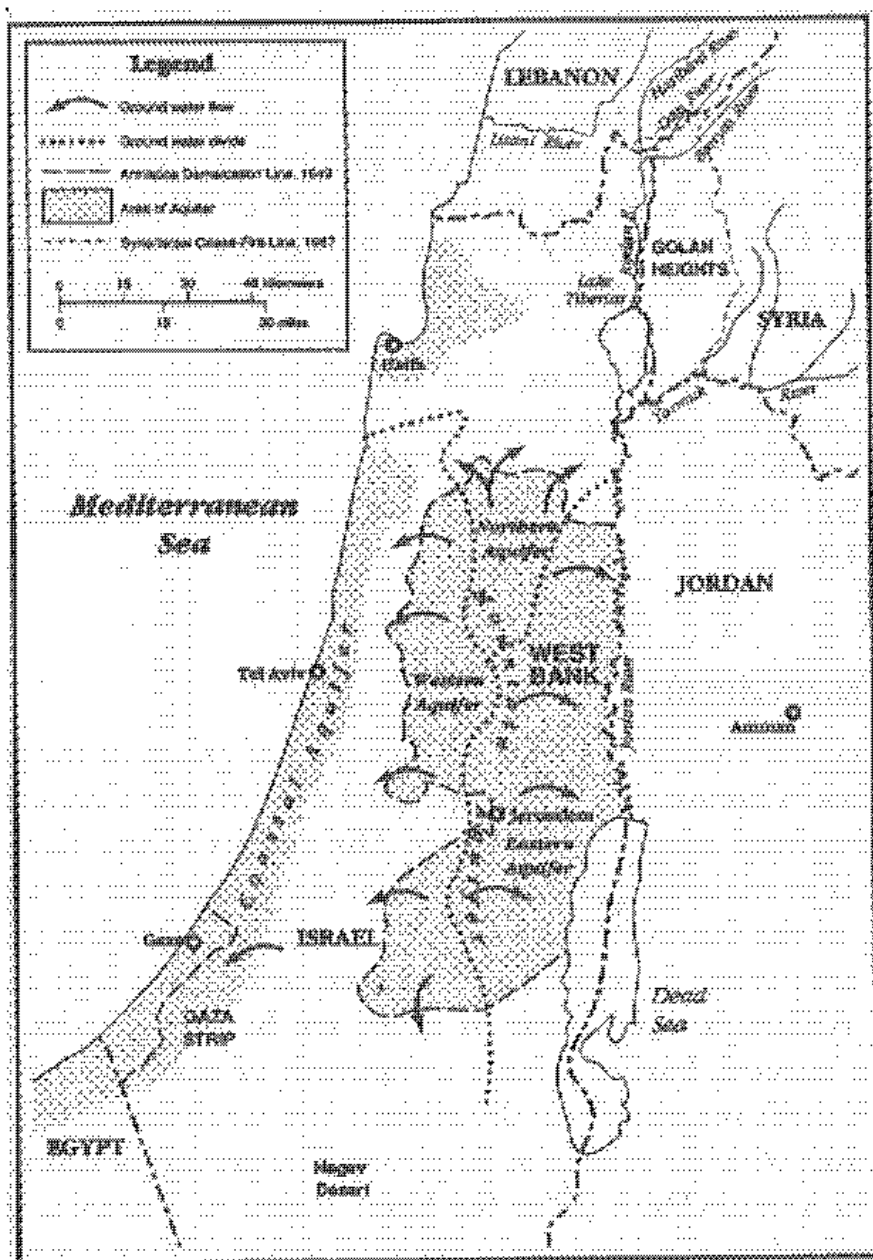

Figure 1. Distribution of the three Mountain Belt Aquifer Basins.

general scarcity of water resources in the region, will be subject to contentious negotiations. Groundwater resources of the main aquifers and basins juxtaposed against the overall consumption are shown in Table 3.

The $6,000 \mathrm{~km}^{2}$ Western Mountain Basin extends from 
Table 3. Groundwater Resources and Overall Water Consumption

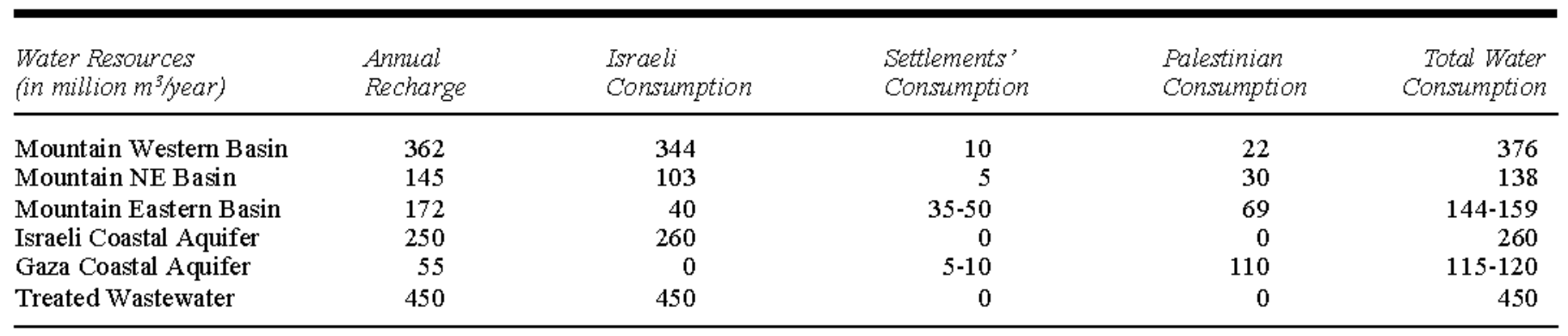

(adapted from Woodrow Wilson School of Public Policy and International Affairs, 1999)

the Judean Desert northward to the Carmel Mountain foothills, and from near the center of the Mountain Belt westward to the Coastal Plain. The basin is underlain by a thick sequence of layered limestone, dolomite, chert, chalk, and marls of the Eocenian age Advat, and the Upper Cretaceous Judea, and Mount Scopus Groups. Over a small percentage of the area in the west, these units are overlain by sand, gravel, and conglomerate of the Quaternary Kukar Group. Precipitation recharges the groundwater system at an average volume of 366 million $\mathrm{m}^{3} / \mathrm{yr}$, along the crests of the Judean-Samarian Anticlinorium territory (Figure 2), which is the central axis of the Mountain Belt, populated traditionally by an overwhelmingly Palestinian majority. Groundwater flows from the recharge zones in a general westward and northward direction across the pre1967 border toward Rosh-Ha' Ayin and Taninim Springs, and well fields along the western edge of the basin in Israel. Groundwater is the principal source of freshwater and is supplied to wells and springs through fractures and caverns in two principal aquifers:

- The Turonian-Cenomanian age aquifer, the most productive aquifer in the basin, consisting of often karstified limestone and dolomitic limestone of geologic unit $\mathrm{Kj}$; and

- The deeper Albian age (Lower Cretaceous) aquifer, of secondary importance, consisting of sandstone and dolomite of geologic unit $\mathrm{Kk}$.

The Northeastern Basin is the northernmost part of the Mountain Belt delimited geomorphologically by the Valley of Jezreel (Esdraelon) in the north and Beit Shean Valley in the northeast. The basin covers an area of about $1,044 \mathrm{~km}^{2}$, and is underlain by a thick sequence of layered limestone, dolomite, chert, chalk, and marl of the Eocenian age Advat, and the Upper Cretaceous Judea and Mount

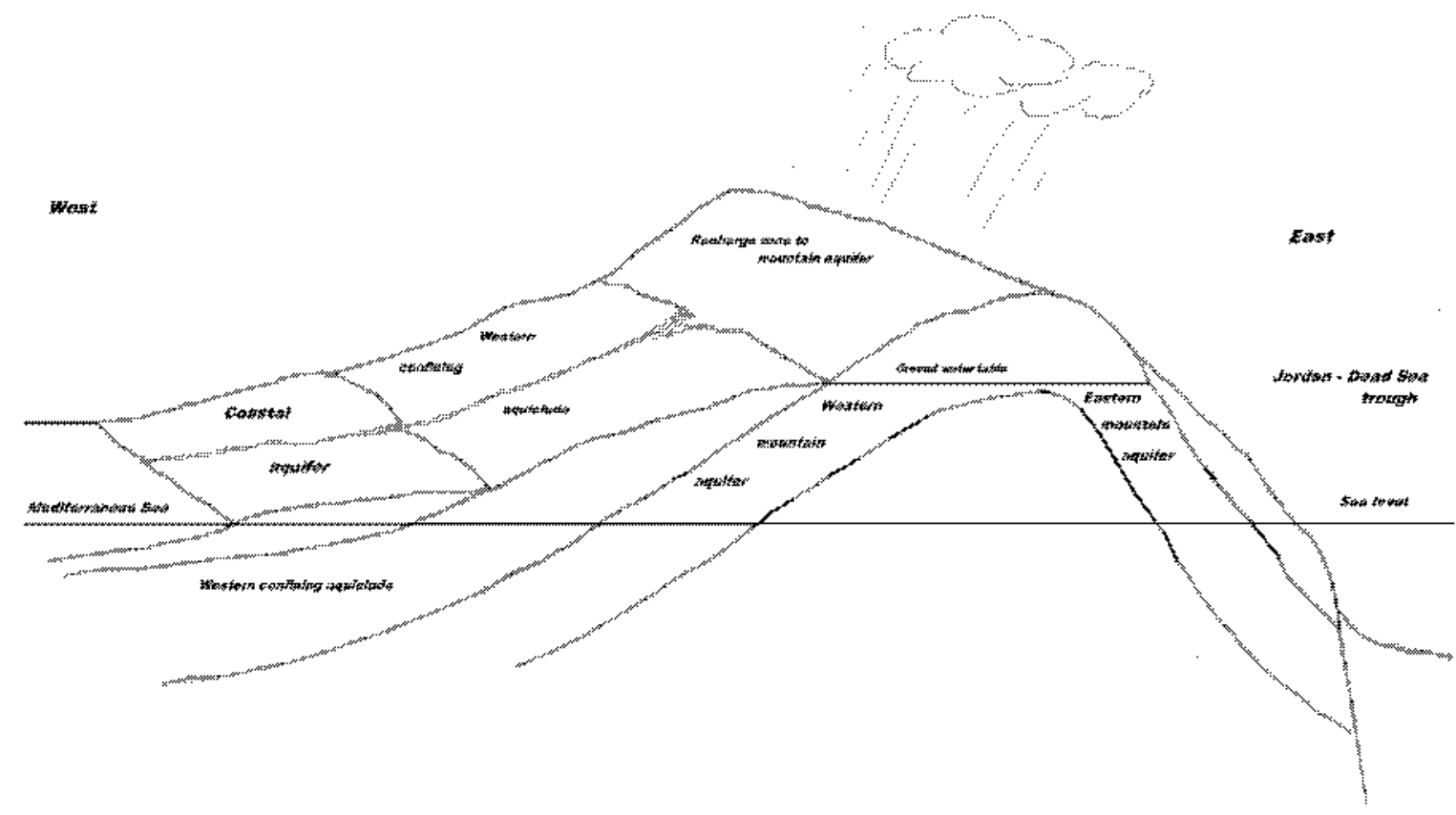

Figure 2. Schematic geological west-east cross section (from the Mediterranean coast to Jordan vall ey, not to scale). 
Table 4. Hydrogeological Data for the Mountain Belt Aquifers

\begin{tabular}{lcrr}
\hline & $\begin{array}{l}\text { Western } \\
\text { Basin }\end{array}$ & $\begin{array}{l}\text { North- } \\
\text { eastern } \\
\text { Basin }\end{array}$ & $\begin{array}{r}\text { Eastern } \\
\text { Basin }\end{array}$ \\
\hline Annual recharge $\left(10^{6} \mathrm{~m}^{3}\right.$ year) & 366 & 145 & 172 \\
Recharge area $\left(\mathrm{km}^{2}\right)$ & 1,800 & 700 & 2,200 \\
Judea and Samaria & 1,400 & 650 & 2,150 \\
Israel (pre-1967 borders) & 400 & 50 & 50 \\
Storage area $\left(\mathrm{km}^{2}\right)$ & & & \\
Judea and Samaria & 2,500 & 700 & 1,950 \\
Israel (pre-1967 borders) & 50 & 650 & 1,950 \\
& 2,450 & 50 & 0 \\
\hline
\end{tabular}

Scopus Groups. Groundwater is recharged by precipitation at an average volume of 145 million $\mathrm{m}^{3} / \mathrm{yr}$ along the northern end of the Samarian Anticlinorium region, which is populated traditionally by an overwhelmingly Palestinian majority and flows generally in a northeast direction across the pre-1967 Israeli border. Groundwater is supplied to wells and springs by two principal aquifers:

- The Eocene aquifer, consisting of limestone and chalk with chert bands of geologic unit Ta; and

- Turonian-Cenomanian aquifer, consisting of often karstified limestone and dolomitic limestone of geologic unit $\mathrm{Kj}$.

The Eastern Mountain Basin covers an area of about $3,080 \mathrm{~km}^{2}$ and includes the eastern part of the Mountain Belt and the steep Western Escarpment of the Jordan Rift Valley. Its entire area is within the West Bank territory, except for a sliver of $50 \mathrm{~km}^{2}$ in Israel. It is underlain by a thick sequence of layered limestone and dolomite of the Judea and Mount Scopus Groups of the Upper Cretaceous (Turonian and Cenomanian) age, that are folded into northsouth trending synclines (lows) and anticlines (highs). The Jordan Rift Valley forms the eastern boundary of the ba$\sin$. Groundwater is recharged by precipitation at an average volume of 172 million $\mathrm{m}^{3} / \mathrm{yr}$ and flows generally in a southeastward direction toward the Jordan Rift Valley. Groundwater is the principal source of freshwater in the basin and is supplied to wells and springs by three principal aquifers:

- The Turonian aquifer, consisting of limestone and dolomite of the uppermost part of geologic unit $\mathrm{Kj}$;

- The Upper Cenomanian aquifer, consisting of intensely karstified limestone and dolomite of the middle part of geologic unit $\mathrm{Kj}$; and

- The Lower Cenomanian aquifer, consisting of intensely karstified limestone and dolomite of the lower part of geologic unit $\mathrm{Kj}$.

The Upper and Lower Cenomanian aquifers, owing to the intense karstification, are the most productive, and occur at depths greater than $250 \mathrm{~m}$. Groundwater generally occurs in synclines that are bounded by faults. Major springs, such as Auja and Hammam Maleh, issue from fault zones and deep-rooted fractures.

To the west of the Mountain Aquifer, located between the Western Mountain Basin and the eastern shore of the Mediterranean Sea, lies a separate aquifer - the Coastal Plain Basin (Figure 2) - which covers an area of about $2,000 \mathrm{~km}^{2}$. The area is underlain by water-bearing sand, sandstone, gravel, and conglomerate of the Quaternary Kinkar geobgicunit Q) that overlie relatively impervious clay, marl, limestone, and chalk of the Tertiary age Saqiye geologic unit (Tp). That impervious aquiclude isolates hydraulically the Coastal Plain Basin from the Western Basin of the Mountain Aquifers. Groundwater in the Coastal Plain Basin is recharged by precipitation at an average volume of 372 million $\mathrm{m}^{3} / \mathrm{yr}$ and generally flows westward toward the Mediterranean Sea. Groundwater is the principal source of freshwater in the Basin, withdrawn primarily from sand, gravel, and sandstone of geo$\operatorname{logic}$ unit $\mathrm{Q}_{1}$.

Approximately $360 \mathrm{~km}^{2}$ of the southernmost part of the Coastal Plain Basin are within the Gaza Strip. The basin is characterized by flat relief and is bounded to the east by the foothills of the Mountain Belt, to the north by the Carmel Mountains, to the west by the Mediterranean Sea, and to the south by the Sinai Desert. In the Gaza Strip, the Basin is grossly overdrawn, with 115 to 120 million $\mathrm{m}^{3} /$ year water budget, while the total local recharge to the Basin is 55 million $\mathrm{m}^{3} /$ year and an additional 7 million $\mathrm{m}^{3} /$ year of an underflow across the border from Israel.

Valleys emerging from foothills of the Mountain Belt in the east, give source to a number of small intermittent to ephemeral streams flowing into Israel across its pre1967 border and discharging into the Mediterranean Sea: Nakhal Soreq, Nakhal Quishon, Nakhal Alexander, and Nakhal Hadera. Nakhal Besor, an ephemeral stream channel that is dry most of the year, crosses from the Northern Negev of Israel into the Gaza Strip discharging into the Mediterranean Sea. None of these streams contributes to the Coastal Plain Basin in any significant or consistent amount.

\section{Israeli and Palestinian Claims to the Region's Groundwater}

Jews and Palestinian have both used the region's groundwaters for generations. Both sides base their claims to this limited resource on historical use, territorial possession, and basic human needs.

The Israelis assert that prior to the Jewish influx into the region, groundwater development was underutilized and supplied only minimal agricultural and domestic needs. During the late $1800 \mathrm{~s}$ and early $1900 \mathrm{~s}$, Jewish farmers 
began developing the region's groundwater resources more effectively to support their expanding farming practices. Thereafter, following the establishment of the State of Israel in 1948, water resource development further expanded to support the budding Israeli economy. By 1967, and prior to Israel's occupation of the West Bank, Israel was already utilizing a major portion of the available water resources of the Western and Northeastern Basins through the full development of springs, rivers, and wells in Israel. Today, while some 80 percent of the source waters of the Western Basin falls as rain in the West Bank, approximately 80 percent of the aquifer's waters are tapped by Israel from wells within its pre-1967 borders. Thus, Israelis claims the right to the water naturally emerging or pumped in Israel and which has historically has been extracted there since before even the creation of Israel. Moreover, they base their claim on the significant damage that would result from the loss of the Israel's current level of use, necessary to meet the country's vital economic and human needs (Shuval, 1999).

Palestinian development of the region's groundwater resources, on the other hand, has been relatively limited. Prior to the establishment of Israel, Palestinians lacked the financial and organizational resources necessary to develop the region's aquifers. While Palestinians did maintain and use various wells and springs in the region, new wells were rarely dug, many natural springs remained unused, and there was little industry or economic growth to spur investment in water resources. Prior to 1948, few Palestinian villages had developed central water supply systems. Later, under Jordanian administration of the West Bank between 1948 and 1967, little if any improvement occurred (Shuval, 1999).

Nonetheless, Palestinians also make claims to the region's groundwaters based on historical use, territorial possession, and human necessity. While they may have not exploited the region's water resources to their full potential, Palestinians have lived on the land for tens of generations. Fathers and grandfathers farmed, raised livestock, and utilized wells and springs for sustenance and development. Furthermore, the Palestinians contend that since most of the region's aquifer recharge falls as rain over the West Bank, by virtue of sovereignty over the territory, they should have first opportunity to use and exploit the resource (Shuval, 1999).

Palestinians also argue that they suffer from severe shortages and point to the huge disparity between the average amounts of water available to each Israeli as compared to that available to each Palestinian. Thus, they contend that based on principles of human rights, as well as on internationally recognized standards of minimum water requirement, they should be accorded a larger share of the water (Shuval, 1999).

In addition, Palestinians and some legal scholars assert that Israel's extraction of water inside the West Bank since 1967 is a direct violation of the Geneva Convention, which applies to international armed conflict and addresses the obligations of a "belligerent occupier." Under the Convention, a belligerent occupier may use the natural resources of an occupied land to support its military forces of occupation. However, it may not use those resources to support its own civilian's activities. This argument is highly contested by Israel and other legal scholars, especially the characterization of the Israeli-Palestinian conflict as being international (i.e., between two or more sovereign states) and, thus, the applicability of the Geneva Convention to the situation. Since this article focuses on the international law governing shared water resources (as opposed to the use of water resources by an occupying power in an international armed conflict), this contention will not be addressed here. More information on this position can be found in Abouali (1998).

\section{Groundwater Resources and International Law}

International law constitutes the rules and norms by which states conduct their actions in relation to other states. In the context of international water resources, the law often termed international water law - strives to delineate riparian states' rights and obligations to the shared waters. Historically, the focus of international water law was on surface waters such as shared lakes and rivers. The use, management, and conservation of shared groundwater resources, on the other hand, received little attention in international legal discourse and political circles, and generally, was absent from bilateral and multilateral agreements.

As the importance of groundwater became more evident in recent years, efforts were made to address this deficiency and to develop norms relevant to this invisible resource. The International Law Association's Helsinki Rules of 1966 (ILA, 1966) and Seoul Rules of 1986 (ILA, 1986) were among the few international documents to directly address the status of groundwater under international law. Due to their non-binding nature, however, the influence of the two Rules on state practice and treaty development has been limited. The organization that drafted these rules was the International Law Association (ILA), a private non-governmental organization, which enjoys no official status in the development of international law. The work of the ILA has always been regarded merely as aspirational in nature and not as hard and fast fules of state conduct. (Dellapena, 1992; 1994). Nonetheless, specific agreements and understandings were reached for managing a number of shared aquifers, including between France and Switzerland, the United States and Canada, and other nations.

Most notable in the development of international law applicable to groundwater was in 1997 when the United Nations General Assembly adopted the Convention on the Non-Navigational Uses of International Watercourses. As a product of the United Nations, the Watercourse Con- 
vention constitutes the first official codification of international law applicable to groundw ater resources. The Convention specifically includes groundwater within its scope by defining "watercourse" (the unit subject to regulation) as "a system of surface waters and groundwaters constituting by virtue of their physical relationship a unitary whole and normally flowing into a common terminus."

Despite this progressive development, a careful review of the Convention reveals that while the applicable rules and norms are reasonably developed, the types of groundwaters subject to those norms are limited. In defining a watercourse, the Convention provides strict criteria for determining whether one or another type of groundwater is encompassed by the Convention. As will be seen, the Convention fails to account for both the Mountain Aquifer and the Coastal Plain Basin.

The definition provides that only groundwaters that are part of a "system of surface waters and groundwaters" and "constituting by virtue of their physical relationship a unitary whole" are encompassed by the Convention. This approach advocates a unitary or comprehensive management scheme of interconnected surface and groundwaters. While self-limiting, it nonetheless acknowledges the important interrelationship of surface and underground water within the hydrologic cycle. When considered in the international context, it appears that for the Convention to apply, it is not necessary for a particular aquifer or for an interrelated surface body of water to traverse an international boundary so long as the system, or any one of its interrelated components (i.e., an interrelated aquifer or river or lake), traverses or flows along an international border. Despite the expanse of the terminology, the definition also imposes very specific limitation on the scope of the Convention. In particular, it restricts the Convention only to "systems," and only to systems that have a "physical relationship" between the inter-linked components. Based on these criteria, it appears that for an aquifer to be subject to international law, it must be physically related to a surface body of water (Eckstein, 2003).

This is further underscored by the definition, which specifically excludes from the Convention groundwater that is unrelated to any surface water. In comments attached to the draft Convention submitted to the United Nations, the Convention's drafters noted that "[i]t follows from the unity of the system that the term 'watercourse' does not include ... groundwater ... unrelated to any surface water" (United Nations, 1994). This intentional exclusion was rationalized on the basis that unrelated groundwater cannot have any untoward effects on any other watercourse (Eckstein, 2003).

Another definitional limitation under the Watercourse Convention lies in the phrase "flowing into a common terminus." The expression was included, in part, to provide a geographic limitation whereby two different watercourses connected by a canal could not be regarded as a single watercourse for the purposes of the Convention (UN,
1991). When applied to groundwater resources, however, the phrase further limits the types of shared groundwater that falls under the scope of the Convention. It specifically excludes groundwater flowing to a terminus different than that of hydraulically related surface water body. While not necessarily ubiquitous, this scenario is not uncommon. Moreover, the phrase probably excludes a single aquifer unrelated to any surface water since the term "common" implies there must be more than one water resource whose flow direction is being assessed (Eckstein, 2003).

Considering the above criteria, both the Mountain Aquifer and the Coastal Plain Basin would be excluded from the scope of the Watercourse Convention. While the Mountain Aquifer traverses the political border between Israel and the Palestinian Territory in the West Bank, it has no physical relationship with any surface body of water, and is, in fact, unrelated to any other identifiable water resource. The Mountain Aquifer, therefore, is not part of a "system of surface waters and groundwaters" and does not flow to a terminus common with another water resource. Moreover, the aquifer flows toward three divergent termini - the water in each of the basins flows in a different direction - thus further excluding it from the definitional criteria for groundwater encompassed by the Convention.

The same can be said of the Coastal Plain Basin, which flows underneath the border between Israel and the Gaza Strip. While the Basin may have some limited connection to a number of intermittent streams, flowing from the West Bank into Israel or from Israel into the Gaza Strip, none of these streams constitutes a source of any consequential or consistent recharge. Thus, it would be difficult to characterize the Coastal Plain Basin and the intermittent streams as a "system of surface waters and groundwaters."

Despite the non-applicability of the Watercourse Convention to the Israeli-Palestinian dispute over groundwater resources, there are other sources of international law that may provide guidance for addressing the dispute. There are now a growing number of examples in which riparian states use the waters of a shared aquifer. From these examples of state practice, as well as from generally accepted norms of international water law, concepts can be extrapolated to provide guidelines for the use, management, and conservation of shared groundwater resources. Of these guidelines, the most notable include the doctrine of hydrological unity, and the principles of equitable and reasonable use, no substantial harm, and good faith negotiations.

The doctrine of hydrological unity recognizes the interrelationship of surface and groundwaters within the hydrologic cycle. It emphasizes that the most effective way to use, regulate, manage, and conserve shared water resources is through a comprehensive scheme that takes into account all interrelated water resources. Thus, states are obligated to consider the watercourse and all hydraulically related surface and undergroundwater resources 
as the unit of measure when implementing schemes for the use, management, and conservation of freshwaters.

States are also obligated to use their shared water resources in an equitable and reasonable manner. The principle of equitable and reasonable use is a utilitarian concept that uses a cost-benefit analysis to maximize the beneficial use of limited water resources while minimizing the burdens. Riparian states - states with direct access to a transboundary river - must take into account the interests of all other riparian states in the use of the shared waters, as well as any necessary conservation objectives, when implementing projects to use or develop the resource (Eckstein and Eckstein, 1998).

In their use of transboundary water resources, states also must not cause significant harm to the interests of other states relying on the resource. Harm is defined as "significant" where it results or threatens consequential effects upon the public health, economic productivity, or the environment of another state, or where it materially interferes with or prevents a reasonable use of the water by another State. The principle of no significant harm, however, is considered subordinate to that of equitable and reasonable use (Eckstein and Eckstein, 1998).

In the event a dispute arises over a planned activity or the potential transboundary impacts of such activity, the states involved have an obligation to employ good faith negotiations in resolving their dispute. In the Lake Lanoux Arbitration case, the international arbitration tribunal concluded that "the reality of the obligations thus undertaken is incontestable and sanctions can be applied in the event, for example, of an unjustified breaking off of the discussions, abnormal delays, disregard of the agreed procedures, systematic refusals to take into consideration adverse proposals or interests, more generally, in cases of violation of the rules of the rules of good faith" (Lac Lanoux, 1957).

While these guidelines offer a basis of law by which states are to conform their conduct, compliance is often subject to state interests and interpretation. What one state may consider equitable and reasonable, another state may think unjust. Thus, application of these principles to a specific dispute, such as that between Israel and the Palestinians, is best left to an unbiased tribunal or third party.

Nevertheless, it is unlikely that - or at best unclear to what extent - these principles might apply to the IsraeliPalestinian situation. Under traditional conceptions of international law, only states can be recognized as possessing rights and obligations; only sovereign state are subjects of international law. To qualify as a state under international law, an entity must have a defined territory, a population, a government, and the capacity to engage in diplomatic or foreign relations. While the Palestinians may be regarded as a people with the Palestinian Authority as their government (though, the Palestinian Authority's own actions often belie this supposition), Israel wields significant control over Gaza and the West Bank, and substantially restricts the Palestinian Authority's ability to govern. Moreover, given the fluid nature of the ongoing Israeli-Palestinian dispute, it remains unclear what borders actually define a specific Palestinian territory that would be subject to international law. Contemporary international law has been interpreted to extend some measure of limited recognition to non-state political entities and even individuals. Such progressive interpretations, though, are still not the norm, and prior to any consideration by a tribunal or third party of the principles and guidelines applicable to the dispute, the status of the Palestinian Territories and the Palestinian people under international law will have to be considered.

\section{Refocusing Israeli-Palestinian Negotiations}

Regardless of the claims, potentially applicable principles and standards, and alleged violations of international law, it is clear that the controversy over water resources will be a difficult one to overcome. During the period prior to the second intifada, there were a number of cooperative efforts made at addressing issues of quality and allocation of water resources shared between the Israeli and Palestinian societies. Nevertheless, neither party has ever agreed to relinquish its claims to what it considers its fair share, and under the present day circumstances, such accommodations are unlikely.

Today, the indisputable fact remains that the region's water resources are insufficient to provide for the needs of both parties. Currently, pumping of the Western Mountain Basin and the Coastal Plain Basin exceed natural recharge, while pumping of the Northern Mountain Basin equals recharge. Moreover, the draught that has gripped the Middle East in recent years threatens the viability of not only the aquifers, but also of Lake Kinneret (Sea of Galilee) - the other chief reservoir of freshwater in the region (Ben-Tal, 2001). Accordingly, even if an international tribunal could achieve a just allocation of the region's current waters supplies, shortages would undoubtedly continue and tensions would re-escalate.

In order to lessen tensions and improve any chance for a compromise over shared water resources, new sources of freshwater must be identified. With growing populations and the need for economic development, especially by the Palestinians, there is a dire need for the Israelis and the Palestinians to shift their focus from accusation and condemnation toward efforts geared at finding new sources of freshwater. Over the years, various ideas have been proposed, including desalination and importing water from other countries. Most of these ideas, however, were discounted as politically, technically, and financially impractical. Yet, given the growing needs, the practicality of these options must be reevaluated.

Desalination has been used effectively in a number of countries where water scarcity is so extreme as to make the cost feasible. In Israel, the cost-benefit analysis has only recently reached the point of feasibility, and plans call for the construction of a commercially viable desalination 
plants, the first one near the Mediterranean city of Ashdod. Plans are also being discussed with the United States to fund a desalination project in the Gaza Strip ("Progress made," 2001). A more ambitious plan being considered is the construction of a canal between either the Mediterranean and the Dead Seas or the Red and the Dead Seas. Using gravity and the 400 meter difference in elevation, turbines would generate electricity that would be used to desalinate sea water (Lazaroff, 2001).

One of the most ambitious schemes for improving the region's poor water situation is the so-called Peace Pipeline. First suggested by Turkey's late president, Turgut Ozal, the plan calls for delivering freshwater through long pipelines stretching from southern Turkey, through Syria or Lebanon, and into Israel or Jordan (Sher, 2000). Given tense relations between Turkey and Syria, and Syria and Israel, as well as the staggering cost of the project, the proposal has yet to be considered seriously. Other more readily accepted ideas for water importation include shipping freshwater in converted oil tankers or possibly gigantic "medusa bags" towed by barges.

Regardless of the scheme, any effort to seek new water sources, however, must be a joint enterprise. Both parties must understand that their future is inextricably intertwined. This is especially clear with regard to the region's shared water resources. In order to deflate tensions and overcome concerns for water security, both parties must be assured that they will have equitable access to freshwater resources. The clearest solution to the water dispute lies in new sources of freshwater and in cooperation.

\section{About the Authors}

Prof. Yoram Eckstein worked for 17 years as a hydrogeologist with the Geographical Survey of Israel, and for the last 27 years as Professor of Hydrogelogy at Kent State University, Kent, Ohio, USA. Email: yeckstei@ geology.kent.edu

Prof. Gabriel E. Eckstein is an environmental attorney and consultant specializing in international water law, and Associate Professor of Law at Texas Tech University, Lubbock, Texas, USA: Email: gabrie1113@att.net.

\section{Discussions open until December 1, 2003.}

\section{References}

Abouali, G. 1998. "Natural Resources under Occupation: The Status of Palestinian Water under International Law." Pace International Law Review 10: 411.

Affaire du Lac Lanoux. 1957. (Spain v. Fr.), 12 R.I.A.A. 281 (16 Nov 1957).

2001. "Progress Made Towards US-Funded Water Project in Gaza Strip." Agence France Presse, 16 Nov 2001.
Ben-Tal, D. 2001. "Embracing the Water Crisis." The Jerusalem Post. 19 Oct 2001. http://www.jpost.com/Editions/2001/10/ 18/Features/Features. 36479.html.

Benvenisti, M. and S. Khayat. 1988. The West Bank and Gaza Atlas. The West Bank Data Base, Jerusalem.

Dellapenna, J.W. 1992; 1994. "Designing the Legal Structures of Water Management Needed to Fulfill the Israeli-Palestinian Declaration of Principles." Palestine Y.B. of Int'l L. 7: 63.

Eckstein, G. 2003. A Hydrogeological Perspective of the Status of Groundwater under the UN Watercourse Convention.

Eckstein, G. and Y. Eckstein. 1998. International Water Law, Groundwater Resources and the Danube Dam Case." In John Van Brahana, et al., eds. Gambling With Groundwater-Physical, Chemical, and Biological Aspects of Aquifer-Stream Relations.

Gleick, P., ed. 1993. Water in Crisis. Oxford: Oxford University Press.

International Law Association (ILA). 1966. "Helsinki Rules on the Uses of the Water of International Rivers and Comments." Report of the Fifty-Second Conference. London, England, United Kingdom: ILA Publications.

International Law Association(ILA). 1986. "Seoul Rules on International Groundwaters." Report of the Sixty-Second Conference. Seoul: ILA Publications.

Lazaroff, T. 2001. A" Bitter End for the Dead Sea?" The Jerusalem Post. 7 June 2001. http://www.jpost.com/Editions/2001/ 04/29/Features/Features. 25267.html.

Sher, H. 2000. "Source of Peace?" The Jerusalem Report. 13 March 2000: 34

Shuval, H. 1999. "Sharing the Wealth." The Jerusalem Post. 16 Nov 1999. http://www.jpost.com/com/Archive/16.Nov.1999/ Features/Article-1.html.

United Nations. 1991. Israeli Land and Water Policies and Practices in the Occupied Palestinian and Other Arab Territories. Report of the Economic and Social Commission for Western Asia. New York, A/46/263.

United Nations. 1991. "Report of the International Law Commission to the General Assembly on the Work of its Forty-Third Session, The Law of the Non-Navigational Uses of International Watercourses." Year Book of the International Law Commission, U.N. Doc. A/CN.4/SER.A/1991/Add.1 (Part 2).

United Nations. 1994. "Report of the International Law Commission to the General Assembly on the Work of its Forty-Sixth Session, The Law of the Non-Navigational Uses of International Watercourses." in Year Book of the International Law Commission, U.N. Doc. A/CN.4/SER.A/1 994/Add.1 (Part 2).

United Nations. 1997. "Convention on the Law of the NonNavigational Uses of International Watercourses." Int'lLegal Material 36: 700 (May 1997).

Woodrow Wilson School of Public Policy and International Affairs. 1999. Allocations of Water and Responsibilities in an Israeli-Palestinian Water Accord: Water Rights in the Jordan Valley.Princeton, New Jersey, USA: Princeton University, WWS 401c. 